\title{
Doing Critical Language Teaching through Tasks: Insights from the Brazilian Context
}

\author{
Priscila Fabiane Farias ${ }^{1, *(\mathbb{D})}$ and Leonardo da Silva ${ }^{2}$ (D) \\ 1 Teaching Methodologies Department, Federal University of Santa Catarina (UFSC), Trindade, \\ Florianópolis 88040-900, SC, Brazil \\ 2 Departamento de Ensino, Pesquisa e Extensão, Federal Institute of Santa Catarina (IFSC), Praia Comprida, \\ São José 88103-920, SC, Brazil; leonardo.silva@ifsc.edu.br \\ * Correspondence: priscila.farias@ufsc.br
}

Citation: Farias, P.F.; da Silva, L. Doing Critical Language Teaching through Tasks: Insights from the Brazilian Context. Educ. Sci. 2021, 11, 223. https://doi.org/10.3390/ educsci11050223

Academic Editor: Graham Crookes

Received: 23 March 2021

Accepted: 27 April 2021

Published: 7 May 2021

Publisher's Note: MDPI stays neutral with regard to jurisdictional claims in published maps and institutional affiliations.

Copyright: (C) 2021 by the authors Licensee MDPI, Basel, Switzerland. This article is an open access article distributed under the terms and conditions of the Creative Commons Attribution (CC BY) license (https:// creativecommons.org/licenses/by/ $4.0 /)$.

\begin{abstract}
Although Brazilian governmental documents have conceived language teaching from a critical perspective, the recent scenario points to a backlash towards critical perspectives on teaching, which have been socially perceived as indoctrination. Since we understand critical pedagogy in additional language classrooms as a necessary emancipatory perspective, this article aims at discussing possibilities for promoting critical language development. More specifically, it draws on two doctoral studies in which teacher-researchers implemented critical task cycles that aimed at promoting critical language development by fostering elementary and high school students' reflections on gender issues. In both studies, tasks were developed to promote learners' communicative and critical development following task-based principles. The comparison of the results, derived from the analysis of learners' interactions during implementation, responses to questionnaires and interviews, and of the teacherresearchers' self-report diaries, revealed not only the feasibility of teaching critically through tasks, but also the positive role of: (1) A critical needs-analysis in designing and implementing critical tasks; (2) the use of critical dialogue for fostering knowledge co-construction; (3) the development of final projects to challenge common-sense discourses. These findings indicate, thus, relevant principles for teaching critically through tasks, emphasizing possibilities and challenges for promoting social transformation.
\end{abstract}

Keywords: critical language pedagogy; task-based principles; additional language teaching; critical tasks

\section{Introduction}

In order to understand any educational context from a critical perspective, it is necessary to go beyond what happens in the actual classroom. This is due to the fact that the classroom is not disconnected or immune from the wider educational, social, political, and economic contexts. In this sense, one could say that one of the challenges of critical language teaching is being able to promote critical consciousness development in a context where doing so is going against the grain.

That seems to be the case of the Brazilian context. Even though Brazil is the home of the critical educator Paulo Freire, and despite the fact that recent documents that guide basic education in Brazil have argued in favor of the development of critical citizenship across the school disciplines [1-3], the last decade has been marked by a backlash in terms of public policies for education. It is not uncommon, for instance, to see headlines in newspapers in which politicians disregard the relevance of Freire's work. Furthermore, the most recent document proposed by the federal government to guide Brazilian education-the National Common Core Curriculum [4] - reveals a reactionary tendency towards a false neutrality, failing to explore citizenship critically and dangerously erasing socially relevant issues such as gender and sexuality from teaching units [5]. In this sense, critical perspectives on 
education — which aim at promoting learners' critical consciousness development-have often been accused of indoctrination [6], which is exactly the opposite of Freire's proposal.

To offer some concrete examples of the current Brazilian context of educational backlashes, in one of the contexts under investigation in the present article, the school was contacted (during the period of data collection) by the Minors' Guardianship Council due to a denouncement made by a parent who argued that some of the content of the "library week" events-which included the screening of films on gender and sexuality-was not appropriate for teenagers. Likewise, on the campus page on Facebook, people-including parents-left comments questioning the relevance of discussing gender during library week. In addition to that, a councilman from the city where the school is located proposed to introduce a bill that would have the objective of prohibiting what was called gender ideology at school. Finally, even within the school itself, reactionary actions took place when some students came up with the idea of including posters in the restroom mirrors about gender inequality which were then defaced by other students. From these facts alone, we can observe resistance regarding gender and critical teaching in general that is certainly not exclusive to specific contexts, but rather a result of the broader reactionary scenario that pervades the Brazilian context, dramatically increasing in the last 5 years.

As teacher-researchers who have been working in the field of Critical Language Teaching with the aim of promoting critical language development in the context of public basic education in Brazil, we often feel threatened. Thus, it is not uncommon that we ask ourselves (or even that we are asked by colleagues): Is it possible to promote critical language teaching in such reactionary times? If yes, then how? In order to answer these questions, first of all, we draw on Freire's perception of the power that esperançar (to hope, in English) has on transformation. As Freire emphasizes, being hopeful alone does not transform the world, as it is not enough to seek transformation. On the other hand, if action comes without hope, "the fight becomes weak and hesitant" [7] (our translation).

In this sense, being critical teachers who believe in critical language teaching as a possibility for transformation, we ground our choices on the fact that critical pedagogy in additional language classrooms of Brazilian schools can be perceived as an emancipatory tool that encourages social change by resisting against the status quo and by promoting critical consciousness development. As we have seen in the examples given above, hegemonic discourses have in fact gained strength and power, promoting alienation and reinforcing certain myths, causing great impact in the Brazilian society and also worldwide. From where we stand, however, this is actually evidence for the urgent need of Critical Language Pedagogy.

Hence, this article aims at discussing possibilities for promoting critical language development in Brazilian additional language classrooms through critical tasks. For that purpose, we draw on two studies in which teacher-researchers implemented critical task cycles that attempted to promote critical language development by fostering learners reflections (and actions) on gender issues. Both studies were conducted in Brazilian public schools: one in elementary education and the other in the context of a technical and technological high school. Moreover, both teacher-researchers developed their teaching materials following task-based principles [8-11] as well as critical language teaching principles [12]. More specifically, therefore, considering information from these two studies, our article is divided into two parts: (1) First, we focus on describing and discussing the two task cycles used in the studies under scrutiny to understand what makes these units critical task cycles, and then; (2) by making reference to data from the two studies, we focus on specific aspects from both critical task-cycles that seem to contribute to learners' critical consciousness [13] and critical language [14] development.

\section{Critical Language Pedagogy and Task-Based Instruction in Brazil: Some Theoretical Tenets}

Critical Language Teaching or Critical Language Pedagogy [12] relies on core elements from Critical Pedagogy (CP) in order to promote additional language teaching from a critical perspective. From this stance, language teaching and learning are understood as 
ideological and should, thus, aim at promoting social justice [12]. In this sense, Critical Language Teaching recognizes the importance of students' local contexts and needs for lesson planning and implementation. Moreover, students' own linguistic background and life experiences become central to the learning process, incorporating "the dimensions of reflection and action, the process of naming reality (theorizing, 'representing'), and the process of changing reality (directed action in the material, historical world)" [15] (p. 9).

Additionally, drawing on $\mathrm{CP}$ principles, critical language teaching emphasizes that promoting action in one's context is as equally important as becoming aware of this context's reality. This is in fact what Freire, back in the 1970s, referred to as "critical consciousness" or conscientização. For Freire [13], people engage in developing and nurturing critical consciousness if they go a step beyond perceiving the existing surrounding conditions and, in fact, also engage in authentic transformation of them.

Finally, one last concept that deserves attention when engaging in critical language teaching is the relevance of critical dialogue. Crookes clarifies that, different from a more literal definition of dialogue, the idea of critical dialogue refers to an opportunity for sharing thoughts during a discussion, while encouraging or pressing "another to consider the basis for their thinking" [12] (p. 64). Critical dialogue is, therefore, a step towards transformation.

Due to its pertinence in education, critical language teaching has conquered significant space in research and praxis worldwide. In Brazil, the field emerged with the work of Freire, who was, during the dictatorship in the 1960s, imprisoned and exiled for his ideas and practices in promoting education for the oppressed. The second phase of Brazilian critical pedagogy started with the Law of Amnesty of 1979, when many intellectuals (including Freire) were able to return to the country and when the word critical had never "been spoken so much before" [16] (p. 435). Cox and Assis-Peterson highlight, however, that during this second phase, the main tenets of critical pedagogy "mainly fertilized the imagination of academics involved with the mother tongue [Portuguese]. Teachers of English stayed on the sidelines of the movement" [16] (p. 436-437). This is probably due to the fact that, at the time (1970s), the communicative approach was very popular among Brazilian English professionals and learning a language meant "acquiring linguistic and communicative competence without a political, ideological dimension" [16] (p. 437). Almost 20 years later, their 1999 study, that tried to find out what Brazilian English teachers knew about and thought of critical pedagogy, pointed out to the fact that critical pedagogy, among English teachers, seemed to be "a matter of interest only to a few academics" [16] (p. 448).

Nowadays, it is possible to state that the area of Critical Language Teaching has developed widely in Brazil, as some Brazilian authors have focused on critical perspectives in language education [17-28]. However, even though the field has increased in the country, there is an urgent need for more research and praxis interested in unveiling critical pedagogy for language teaching, especially considering the current political and educational Brazilian scenario. Siqueira [29], for example, in a study conducted with a group of high school Brazilian teachers in the northeast of the country, found out that teachers seem to be more critical in theory than in practice, they commonly engage in reflection, but this is turned into little action, they are totally in favor of enforcing a relationship between critical pedagogy and FL teaching, but feel they lack the theoretical background, and that they are underqualified to carry out such a task (p. 202).

In this sense, our aim in this piece is to contribute both to the CP research area and to teachers' practices in schools by discussing possibilities for critical language teaching that may result in the promotion of learners' critical consciousness and critical language development. As a way to devise possibilities for doing critical language teaching in real classrooms, we rely on principles of the task-based approach (TBA) since, as we argue throughout this paper, it offers us methodological possibilities for engaging in our critical work.

Even though the task-based approach (TBA) can be understood as a branch of the communicative language approach, and despite the fact that it has been mainly conceived 
and explained from a psycholinguistics perspective, it is our belief that it may serve as an appropriate venue for the conceptualization of teaching practices that can account for the complex needs of our students-especially by including a critical perspective for understanding these needs. For the sake of this argument, we strongly rely on the understanding that theories for language teaching and learning, similar to any other science field, need to be of social relevance. It could also be argued that some authors in the TBA field, such as Ellis [9] and Long [30], have made similar points. Even though Ellis does not focus on critical stances towards language teaching, in his 2003 book [9] he briefly highlights that a critical perspective "forces us to go beyond the psycholinguistic rationale [...] in order to examine the social, cultural, political, and historical factors that contextualize teaching and how it takes place" (p. 333). Moreover, in his 2015 book, Long [30] goes further and indicates that a socially-oriented perspective may recognize the social role of language learning, claiming that "those who oppose LT (of any kind, not just TBLT) having an emancipatory function need to recognize that a hands-off attitude is itself as 'political' and just as interventionist, for it helps perpetuate the status quo" (p. 73). In the same book, Long argues for the importance of recuperating the philosophical underpinnings of the task-based approach-l'éducation integrale, individual freedom, rationality, emancipation, learner-centeredness, egalitarian teacher-student relationship, participatory democracy, and mutual aid cooperation-as these seem to go beyond the cognitive rationale and contribute to social justice in different ways since, as the author himself puts it, even though language teaching alone cannot solve or compensate for the injustice in the world, "it should strive not to perpetuate matters or to make them worse" (p. 64).

Considering the relevance of this debate and looking at the Brazilian context, one could say that even though a growing number of Brazilian studies have focused on taskbased principles in real language classrooms [31-40], the majority of them have followed a cognitively-oriented perspective to the area, focusing on issues such as the roles of task planning and feedback, technology-mediated tasks, and the design and implementation of tasks for different language learning contexts. More recently, however, two doctoral dissertations $[41,42]$ have investigated the effects of implementing task-cycles designed from a critical perspective for English language teaching in the context of Brazilian basic education. As both Farias [41] and Silva [42] explain, a critical cycle of tasks-or a critical task-cycle-comprises a set of tasks that are connected to each other, and hence, lead to a cyclical learning process. As we shall see, this article explores these two studies in order to shed light on the challenges and possibilities involved in designing and implementing what is defined as critical cycles of tasks.

Before presenting more details of each study and focusing on the goals of this piece, it is also relevant to discuss the core principles of tasks that have guided both studies. First of all, we highlight that they both draw on Ellis' $[8,9]$ definition for a task, which corresponds to a language activity that directs learners' attention to meaning-making by giving them a communicative outcome to be achieved, and which resembles activities from the real-world. Moreover, both studies also conform to Ellis's [9] modular approach to task design, in which two separate modules are conceived-a communicative module, seen as the main component of the approach, which "consists of linguistically unfocused tasks", and a code-based module, seen as a secondary component, which can be taught "by means of focused tasks such as structure-based production tasks, interpretation tasks, and consciousness-raising tasks" (p. 236). Ellis et al. [43] highlighted that "the difference between the two types of tasks lies in their design; whereas unfocused tasks are designed to elicit general samples of language use, focused tasks are designed with a specific language item (typically a grammatical structure) in mind" (p. 38).

Although some authors have argued that this way of doing task-based instruction is undesirable (e.g., Long [30]), others have perceived it as helpful (e.g., DeKeyser [44]). In the case of Farias [41] and Silva [42], the choice for this approach is grounded on its possible positive impact since learners have the opportunity to focus on form, while maintaining their main focus on meaning. Moreover, in consonance with a learner-centered perspective, 
students have the chance to analyze the language and create their own understanding of a rule-based system that is also significant since it derives from the context and from language in use. Additionally, it is important to mention that Ellis' proposal for taskbased language instruction was chosen since it seemed to better fit the various needs within the two teaching contexts. As we shall further explore in a following section, during the critical needs analysis process, some significant needs were perceived and considered for material development, such as learners and schools' expectations, learners' daily activities that may require or benefit from additional language development, and documents that have an influence on teachers' decisions such as school syllabus, textbooks, and government documents.

Finally, the idea of a cycle of tasks derives from Skehan's [10] understanding of how, within each task of a task sequence, learners are encouraged to revisit their learning and reflect on their development process in different ways, as the process of language learning does not take place in a linear, cumulative manner. In this sense, following Skehan [10], a cycle of tasks is divided into three phases: pre-task phase, mid-task phase, and post-task phase. Each phase may contain one or more tasks. Pre-tasks may either introduce new elements or reorganize the existing elements in the learner's language system in order to prepare students for the coming task, easing the processing load they may encounter. Mid-tasks, then, focus on improving performance. In this sense, mid-tasks should neither be too easy nor too difficult, so the learner is able to communicate the intended message. Finally, post-tasks are supposed to aid the learner in focusing their attention on aspects that were not attended to during task completion. They may also be used as reflective tools for assessment or as an opportunity for repeating the task, aiming at improvements.

As proposed by Farias [41] and Silva [42], hence, a cycle of tasks is critical when it aims at critical language development and critical consciousness development. From this perspective, a critical task-cycle also follows the principles of critical language pedagogy, thus promoting non-hierarchical co-construction of meaning through critical dialogue. More information on aspects of critical task-cycles are given in the following sections.

\section{Contextualizing the Research: Information from Both Studies}

As previously mentioned, data from two studies [41,42] are considered here as an attempt to illustrate possibilities for critical language teaching of English as an additional language in two public schools in Brazil, located in two different cities in the southern state of Santa Catarina. Both studies are unpublished doctoral dissertations, each one conducted by an author of this piece.

Study 1 [41] was carried out with a group of fourteen additional language learners enrolled in the 7th grade of a federal public school located in Florianópolis, the capital of the state. Data collection took place in 2016. Study 2 [42] was conducted in Itajaí (a city located about 70 miles from the state's capital) with a group of 20 students enrolled in their fifth semester of a mechanical technician high school program at a federal public institute. Data collection happened in 2017. The reason why the task design process as well as the results of both studies are considered in this article has to do with our main goal: to discuss possibilities for promoting critical language development. Hence, by looking at the task development process and by drawing on the results of the two studies (so far unpublished), our purpose here is to compare them with the aim of understanding what lies behind designing and implementing a critical cycle of tasks.

It is important to mention that the teacher-researchers of each study had been teaching the investigated groups for over a year, so they were acquainted with their specific contexts. Moreover, a detailed needs-analysis process was carried out by each teacher-researcher to inform materials design and implementation (more details from the needs-analysis are presented in the following sections). After the needs analysis, the teacher-researchers in both studies developed critical task-cycles specifically designed for each teaching context and according to learners' needs. Both task-cycles followed task-based principles [8-11] as well as critical language teaching principles [12]. 
Data collection in both studies happened during and after the implementation of the task-cycles. In each study, data were collected from learners' interactions during implementation (classes were filmed and transcribed). Moreover, questionnaires and interviews were used to unveil learners' perceptions of their own learning process. Both teacher-researchers kept self-report diaries in which they reflected on the process of planning and teaching while using critical tasks.

In this article, as previously mentioned, results from both studies were considered and compared, aiming at specifically discussing possibilities for critical language teaching in Brazilian education. Even though extensive sets of data resulted from the two studies, in addition to looking at the design of each task-cycle, we direct our focus here to three common aspects of the two studies which emerged from data comparison: (1) The use of critical needs-analysis; (2) the promotion of critical dialogue; and (3) the development of final projects. In this sense, the common features of the two studies seem to reveal relevant principles for teaching critically through tasks.

\section{Critical Task-Cycles: What Do They Look Like and How Do They Work in Practice?}

In order to tackle the challenges and possibilities involved in teaching English from a critical perspective, we first focus on describing and discussing the two task-cycles designed and implemented in the two studies herein contrasted and analyzed [41,42]. We do so since it is our understanding that directing our gaze not only to empirical evidence on the use of critical task cycles but also to the process of designing and implementing them is paramount if our purpose is to inform research as well as teachers/practitioners.

Critical sample materials "find relevance to the extent that they can serve as models on how to implement the principles of critical language teaching" [25]. Drawing on Crookes [12], who emphasizes the significance of critical teaching materials as an opportunity for teachers to have contact with concrete ideas on how to go about teaching critically, the authors explain that the goal behind critical sample materials is not to provide a recipe of what or how to teach, but rather to share practical experiences of critical language teaching as a way to motivate teachers interested in critical teaching or even to offer a start by illustrating core principles that may aid in grounding pedagogical choices that will be made according to each teaching context.

In this sense, our main purpose in this section is to describe and discuss the critical task-cycles developed and implemented in the studies under scrutiny, especially since critical task-cycles could be perceived as a new kind of material in the additional language teaching field. As discussed in the first article of this issue [45], there seem to be some important converging aspects between TBA and Critical Language Pedagogy. In this sense, from the point of view of a language teacher trying to combine theoretical knowledge and practice, there seem to be core aspects of both TBLT and CP relevant to procedures. Therefore, it is our belief that the use of tasks for additional language development, combined with a critical perspective towards language teaching-resulting in what we call critical task-cycles - can be a powerful tool to be used by language teachers aiming at critical consciousness and critical language development.

Before engaging in the main discussion of this section, one last consideration must be made. As previously mentioned, the materials developed in both studies were based on the results of a careful critical needs analysis that was conducted by the teacher-researchers and that included not only information derived from learners themselves but also from other sources such as the school, textbooks, governmental documents, and the teachers' experience and familiarity with each educational context (see Section 5.1). In this sense, the decisions that were made in the development and implementation of each pedagogical task described took into consideration the information collected during this needs analysis process, which is described and analyzed in detail in the next section. As we shall see later, the critical needs analysis was perceived as one of the central aspects for the promotion of critical language development in the two studies. The following section, hence, describes 
and discusses the two critical task-cycles that were used in the studies being compared in this article.

\section{The Two Critical Task-Cycles}

In study 1 [41], the task-cycle was composed of seven tasks that discussed gender representation in society. The first two tasks were part of the pre-task phase and aimed at providing students with language and content input on the cycle's theme (gender representation) as well as raising students' awareness about it. Tasks 3,4 , and 5 were part of the mid-task phase, in which students were asked to react to different texts they were presented with, which gave them the chance to continue the critical reflection process. It was also during the mid-task phase that students were introduced to narrative genres as well as exposed to more extensive linguistic input. Then, the main task of the whole cycle was presented and it required students to write stories about someone in their school community, attempting to challenge gender stereotypes within that context in order to share their narratives in a school Facebook page. Finally, during the post-task phase, with Tasks 6 and 7, students had the chance to rewrite and improve their story. Moreover, in this phase students were required to once again reflect upon and report on their views in relation to the theme that had been discussed. Table 1 below shows a summary of the critical task-cycle used in study 1.

Table 1. Critical cycle of tasks in study 1.

\begin{tabular}{|c|c|c|}
\hline Phase & Task & Task Goals \\
\hline \multirow{2}{*}{ Pre-task } & Task 1-Brainstorming Game & $\begin{array}{l}\text { To play a Q\&A game in English that tackles preferences and } \\
\text { opinions in order to: (a) Reflect on how gender bias can be formed; } \\
\text { (b) be exposed to and comprehend input on gender representation. }\end{array}$ \\
\hline & Task 2—\#LikeAGirl & $\begin{array}{l}\text { To watch a video in English that discusses gender bias in order to: } \\
\text { (a) Reflect on how gender bias can be formed in the media; (b) be } \\
\text { exposed to and comprehend input on gender representation. }\end{array}$ \\
\hline \multirow{3}{*}{ Mid-task } & Task 3-Yes, They can & $\begin{array}{l}\text { To read news pieces in English that present projects that challenge } \\
\text { gender bias in order to: (a) Reflect on/learn about other } \\
\text { possibilities for gender representation that challenge gender bias; } \\
\text { (b) be exposed to and comprehend input on gender representation. }\end{array}$ \\
\hline & Task 4-I wanna see you be brave & $\begin{array}{l}\text { To watch movie trailers in English that tell the stories of two } \\
\text { women who have challenged gender bias in order to: (a) Reflect } \\
\text { on/learn about other possibilities for gender representation that } \\
\text { challenge gender bias; (b) be exposed to and comprehend input on } \\
\text { gender representation. } \\
\text { To read an excerpt in English from a speech on stereotypes and bias } \\
\text { in order to: (a) Reflect on how stereotypes are formed; (b) be } \\
\text { exposed to and comprehend input on gender representation; } \\
\text { (c) understand how the simple past can be used to tell stories. }\end{array}$ \\
\hline & Task 5-Humans of our school-On the move & $\begin{array}{l}\text { To plan and conduct an interview with people from the school } \\
\text { community in order to: (a) Reflect on the school community and } \\
\text { gender representation; (b) write a narrative text to challenge gender } \\
\text { stereotypes in their local context. }\end{array}$ \\
\hline \multirow[b]{2}{*}{ Post-task } & Task 6-Humans of our school-Reviewing & $\begin{array}{l}\text { To reread and rewrite their own text after feedback in order to } \\
\text { better express ideas. }\end{array}$ \\
\hline & Task 7-What did we learn? & $\begin{array}{l}\text { To post their texts in social media in order to challenge gender bias } \\
\text { in their local context; } \\
\text { To read and react to their classmates' posts in order to reflect on } \\
\text { other aspects of their local context; } \\
\text { To reflect on their development in the task-cycle in order to } \\
\text { understand their learning process. }\end{array}$ \\
\hline
\end{tabular}


In study 2 [42], the task-cycle was also composed of seven tasks. In the pre-task phase, students had the chance to reflect on different professions and the ways in which they are commonly seen from a gender-biased perspective (Task 1 ). Since the idea was for them to be able to understand the ways in which the media constructs such stereotypical notions, in Task 2 students gathered information on the media texts they usually consume and reflected on the ways in which characters from those texts are presented. In the mid-task phase, students explained their opinions about the media characters' representations to their colleagues (Task 3) and also analyzed some statistics on female representation in different professions (Task 4). Then, considering the groups' discussion and also the scientific evidence analyzed, they compared the ways in which women and men are representedespecially in the world of work. In Tasks 5 and 6, students had the opportunity to get acquainted with initiatives that aim at fighting against media stereotypes by reading a piece of news (Task 5) and, more specifically, watching a video on a Mechanics program from an institution abroad narrated from the perspective of a female student (Task 6). Finally, in the post-task phase (Task 7), they collected data on gender in their context of study and created an infographic with statistics about gender in their reality. Table 2 below shows a summary of the critical task-cycle used in study 2.

Table 2. Critical cycle of tasks in study 2.

\begin{tabular}{|c|c|c|}
\hline Phase & Task & Task Goals \\
\hline \multirow{2}{*}{ Pre-task } & Task 1-The world of work & $\begin{array}{l}\text { To guess the professions of different people based on their images } \\
\text { in order to reflect on how our views regarding professions may be } \\
\text { gender-biased. }\end{array}$ \\
\hline & Task 2-The world of media & $\begin{array}{l}\text { To interview classmates in order to find out about the presence of } \\
\text { media in their lives and reflect on the representation of the } \\
\text { professional world in different media texts. }\end{array}$ \\
\hline \multirow{4}{*}{ Mid-task } & Task 3-Gender in the media & $\begin{array}{l}\text { To present to the class the profile in English of one of the main } \\
\text { characters of a media text in order to: (a) Reflect on gender } \\
\text { representation in the media; (b) be exposed to and comprehend } \\
\text { input on gender representation. }\end{array}$ \\
\hline & $\begin{array}{l}\text { Task 4-Understanding the effect of media in } \\
\text { women's lives }\end{array}$ & $\begin{array}{l}\text { To read infographics with statistics on media representation in the } \\
\text { US in order to: (a) Understand the effect of media representation } \\
\text { on gender; (b) be exposed to and comprehend input on gender } \\
\text { representation. }\end{array}$ \\
\hline & Task 5-Fighting against media stereotypes & $\begin{array}{l}\text { To read advertisements and news pieces in order to: (a) Reflect on } \\
\text { gender-biased media representation of the professional world; } \\
\text { (b) get to know a project fighting stereotypes associated with the } \\
\text { engineering profession; (c) be exposed to and comprehend input } \\
\text { on gender representation. }\end{array}$ \\
\hline & Task 6-The mechanical technician profession & $\begin{array}{l}\text { To watch a video that presents a girl's report and read the } \\
\text { brochure from a US North-American college in order to: } \\
\text { (a) Compare them to their own program; (b) be exposed to and } \\
\text { comprehend input on gender representation. }\end{array}$ \\
\hline Post-task & Task 7-Creating an infographic & $\begin{array}{l}\text { To conduct research about women in the mechanical technician } \\
\text { profession/program in order to: (a) Reflect on school community } \\
\text { and gender representation; (b) create an infographic as a means to } \\
\text { challenge gender stereotypes in their local context. }\end{array}$ \\
\hline
\end{tabular}

Considering both cycles, keeping in mind the main goal of this section: understand what critical task-cycles can look like and how they can work in practice, some important common aspects deserve to be highlighted. First of all, in the pre-task phase, the tasks designed in both studies attempted to develop language from a critical perspective by exposing learners to written and/or oral input and giving them the opportunity to, through comprehension activities, reflect on gender representation both in micro and 
macro contexts. In other words, during this stage learners reflected upon and understood important aspects related to the theme (gender representation), while also focusing on comprehending the linguistic input, therefore, developing comprehension language skills, and activating/restructuring previous schemata while dealing with new form-meaning relationships [10]. Henceforth, the pre-task phase, in both studies, through input-processing, aimed at: (1) establishing the target language of the main task while also reducing its cognitive load, following the principles established by Skehan [10,11]; (2) promoting critical reflection on the main theme (gender) by providing opportunities to reflect upon existing discourses.

When it comes to the mid-task phase, Skehan [10] explains that it corresponds to the moment in which the actual task is carried out and learners engage in fulfilling the main outcome of the cycle. During this stage, tasks should be neither too difficult nor too easy and attention to either form or meaning should be manipulated to guide learning. In order to achieve these purposes, the mid-task phase of the cycle of tasks in study 1 was composed of three main tasks and, in study 2, it was composed of four main tasks (see previous tables for more details on the tasks). Some relevant aspects of this phase are now further explored.

Firstly, both cycles focused on presenting, comprehending, and reflecting upon a great deal of input on language and the theme. In this sense, the tasks used in this phase attempted to promote critical language development by providing learners with rich and authentic input, engaging them in input-processing and restructuring while also promoting critical reflection. Moreover, the material in this stage also introduced samples of the specific genre (narratives in cycle 1 and infographics in cycle 2) that learners would be asked to work with later on, exploring these texts from a social-discursive perspective through the tasks. Figure 1-which corresponds to the initial steps of task 4 in critical task-cycle 2-[42] illustrates these aspects.

Secondly, in the mid-task phase of both studies, students created short texts, experimenting with language and vocabulary related to the theme they would later on have to write about. Figure 2, which illustrates these aspects, represents a section of Task 4 in critical task-cycle 1 [41].

Finally, another interesting aspect in the mid-task phase of both critical task-cycles is that the two units make use of language consciousness-raising tasks [9] to deal with form in a communicative context. As Ellis [9] explains, language consciousness-raising tasks are the ones "where the content of the task becomes a grammatical feature" (p. 230). In this sense, the main content of the task is the rule system itself, which is brought by the analysis of language in use. Thus, linguistic knowledge is built collectively by the learner with the guide of the teacher, peers, and the task itself. In both studies, this was done through initiating the process with unfocused comprehension tasks of written texts, which also made use of input-enhancement techniques, and then approaching the form through focused tasks that created opportunities for metalinguistic analysis. Henceforth, while working on the mid-task phase, learners were provided with chances of reflecting upon meaningful input, while directing attentional resources in order to notice form-meaning relations more explicitly [46].

Turning our attention to the main task of both critical task-cycles, learners were asked to carry out a task with a focus on challenging and transforming their local contexts, aiming at promoting social justice. That is, as we can observe in Figure 3 taken from critical taskcycle 1 [41], learners interviewed people in their school who seemed to challenge gender stereotypical representations and used their interviews to write a narrative that would then be posted on a school Facebook page. In Figure 4 taken from critical task-cycle 2 [42], learners collected data on gender representation in their program and created an infographic with statistics on gender that would then be shared with the school community. Both main tasks created opportunities for critical language and critical consciousness development. 
TASK 4.

Part 1. a) Now let's look at the following infographic. Answer the following questions in Portuguese.

I) Where can this text be found?

II) What is its objective?

III) Do you think infographics are an interesting way of presenting information?

b) Now read the text below in more detail and complete the table with the appropriate information.

De acordo com o infográfico...

\begin{tabular}{|l|l|}
\hline Qual é o foco dos comerciais feitos para \\
mulheres?
\end{tabular}

Figure 1. Task 4 (Part 1) in critical task-cycle 2.

Finally, having in mind the post-task phase, learners in both studies were given the opportunity to review and improve language production as well as to reflect upon their work focusing both on language and the theme. Therefore, in this stage, they engaged in restructuring and reflecting, working on both critical language and critical consciousness development.

Bearing in mind the common aspects of both critical task-cycles, it is possible to point out some elements that make these two units critical task-cycles:

(a). A task-based framework $[10,11]$ that organizes the sequence of tasks into pre-task phase, mid-task phase, and post-task phase;

(b). A clear communicative outcome (since learners produce language with a purpose in mind for their main task - a narrative to be posted on Facebook in cycle 1 and an infographic to be shared with the school community in cycle 2), as well as critical outcomes (both main tasks invite learners to challenge stereotypical gender representations and to engage in transformative action of the local context); 
(c). Opportunities for critical language development by being exposed to, engaging, and even meta-analyzing linguistic input on the theme being discussed while also engaging in language production;

(d). Opportunities for critical consciousness development by reflecting on and challenging texts and discourses in society, with a focus on social justice and transformation of local contexts.

These elements are further explored below as we focus on data gathered from both studies.

\section{Task 4 - I wanna see you be brave!}

1) Watch the movie trailer that tells the story of Lizzie Valesquez. Number the cards according to the chronological order of the events in her life. After you are finished, paste them in the space below.

\section{( )}

Lizzie has an undiagnosed syndrome so she didn't gain any weight.

\section{( )}

One day, Lizzie decided to look for music on YouTube.

\section{( )}

She found a video of her with the title "The World's Ugliest Woman". only 4 lines to complete this task. You may use the vocabulary you learned in activity 1 , if you consider necessary.

\section{( )}

Lizzie became famous and started giving many talks around the world about beauty and women appearance

Figure 2. Task 4 (part 1) in critical task-cycle 1. 
2) Now, it's time to work on your post. First, review all the material you have from the interview (photos, recording, notes). Then, create an outline to your story. Remember: you must write a 15 line story at most. So, you have to summarize and select the most important information your interviewee gave you.

Story Outline Example

This is the story of Priscila. She is a teacher at xxxx and she is $\mathbf{3 0}$ years old. When Priscila was a child, she liked playing soccer with boys. But they didn't let her play with her. One day, she started a girls' soccer team and her father became the coach. They played together, practiced soccer and had fun! They even participated in competitions! Priscila said this was a very important part of her childhood. She believes sports have no gender!

\section{Story outline}

Introduction - Present the person interviewed. Include this person's name and some details of this person's identity (age, profession, etc).

Ex: This is the story of.... She is a student at xxxxx and she is ... years old.

Part 1 - Start telling the person's story. Present the first important event of the story.

Ex: When ... was a child, she...

Part 2 - Continue the story presenting a turning point. This is the most important moment of your story, when an event happens that impacts the whole story.

Ex: One day...

End - Finish your story by adding a quote from your interviewee. Ex: ... said that...

Figure 3. Task 5 in critical task-cycle 1. 
TASK 7.

Now you are journalists!

Part 1. First, you are going to collect information about women in the profession of Mechanics and in the mechanical technician program at IFSC. For this activity, you are going to work in groups. Write down the name of your group members below.

Group members:

Here are some suggestions of topies:

- COMPARE THE SALARIES OF MEN AND WOMEN IN THE AREA OF MECHANICS

- $\quad$ COMPARE THE NUMBER OF STUDENTS (MEN AND WOMEN) IN THE MECHANICS PROGRAM AT IFSC

- $\quad$ COMPARE THE NUMBER OF TEACHERS (MEN AND WOMEN) IN THE MECHANICS PROGRAM AT IFSC

- COMPARE THE NUMBER OF WOMEN AND MEN IN THE AREA OF MECHANICS REPRESENTED IN THE MEDIA

a) Choose a topic of your preference and write it down.

Topic chosen:

b) Now collect the information and then write down the results in the table below.

$\underline{\text { Results }}$

Figure 4. Task 7 in critical task-cycle 2.

5. A Comparison of the Results from Each Study: Principles for Teaching Critically through Tasks

In the previous section, we described and discussed both critical task-cycles that were implemented in studies by Farias [41] and Silva [42] with the aim of understanding what makes these two units into critical task-cycles. In this section, we turn the discussion to findings from both studies and, by comparing data and their results, we focus on specific aspects of the critical task-cycles that seemed to have contributed to learners' critical consciousness and critical language development. Our goal in this section, hence, is to 
present and discuss aspects of both studies that are here perceived as relevant principles for teaching critically through tasks.

As previously mentioned, in each study a teacher-researcher working at a public Brazilian school implemented critical task-cycles designed specifically for the needs presented in the context. Data from learners' responses to activities, questionnaires and interviews, classes' transcriptions as well as teacher-researchers' self-report diaries were considered. After careful examination of these data, a comparison between the studies was made focusing on unveiling aspects that seem to entail critical language teaching through task-cycles. The comparison of results indicated the relevance of three principles for teaching additional languages critically through critical task-cycles: (1) The use of critical needs-analysis to approach learners' contexts; (2) the use of critical dialogue for fostering knowledge co-construction; (3) the development of final projects to challenge common-sense discourses. Each aspect is now explored in detail.

\subsection{The Use of Critical Needs-Analysis to Approach Learners' Contexts}

Both from the perspective of the task-based approach and from the perspective of critical language teaching, the students are at the center of the teaching and learning process. Therefore, it is necessary to investigate learners' wants and needs in order to develop activities that will make sense and be appropriate for their lives.

In both studies, in addition to being acquainted with the school life and with the classes in which the investigations took place, the teacher-researchers also developed profile questionnaires in order to have a more general understanding of students' needs. Moreover, documents such as school syllabuses, textbooks, and even governmental documents were considered in this analysis. In this sense, the objective was to conduct a needs analysis from a critical perspective [47], going beyond the general idea of identifying specific topics or functions that the students thought they should learn. In this sense, it is important to realize that the position of the researchers as teachers who are part of the school context was helpful for analyzing and understanding the data that was gathered through the questionnaires. It is also worth mentioning that the purpose was not to extensively quantify all of the students' responses, but rather to describe the most significant trends that were observed through their answers so as to shed some light on the development of the task-cycle to be implemented.

Therefore, in both studies, the implementation of a critical needs analysis $[12,47]$ was relevant in order to understand the specificities of the context of investigation and on defining a specific topic of study that would be relevant for the students' context. Moreover, the understanding of the context guided the teacher-researchers' choices in the implementation process.

More specifically, in the case of study 1 [41], the needs analysis process revealed a few pertinent demands derived from the context being investigated: the expectation for a communicative focus in additional language development, the need to approach a real-world linguistic outcome to be achieved, and the need to discuss a theme relevant to the learners' lives. Concerning the first two aspects, learners reported that they used English mostly on the Internet, typically engaging in social networks, playing games, using applications, and watching movies and television series. Moreover, data from the needs analysis showed that learners were commonly required to write narrative texts, that is, to either create stories for their own characters in games or to write about their own life as part of their social network interactions. Therefore, considering these aspects, writing narratives for digital media was the real-world linguistic outcome selected for the main task in the critical task-cycle 1. The idea, therefore, was to offer learners an opportunity to write stories in the target language that would later be shared through social networks, preparing them for engaging in an activity that is part of their daily lives, whilst also learning English.

Additionally, the theme of gender representation was chosen considering the fact that this topic seemed to appear in many class discussions, since students' understandings of 
gender differences were perceived as influencing classroom (and the school as a whole) dynamics. In this sense, the decision to discuss gender representation was a way to motivate students to reflect on the stereotypes they might have regarding their own and other people's gender representations, as well as a way of empowering students to talk about and perform their own identities.

Similarly, in study 2 [42], even though the students did not mention explicitly the theme of "gender relations" in the questionnaires (they actually mentioned broader terms, such as "prejudice", "social difference", etc.), from the teacher-researcher's experience in the Mechanics program, he could notice the sexism that seems to be present in the popular understanding of the area. In his diary, he reported, for instance, that the coordination of the school often has parents asking whether courses that would be "more female appropriate" were not offered. On top of that, he also reported that some female students had come to him reporting cases in which they were underestimated or said to be in the "wrong place" for studying in a Mechanics program. Moreover, all of the Mechanics teachers in the institution were male at the time of the data collection - the only female teachers the students had were the ones from the common-core high school disciplines, such as Biology, Portuguese, Spanish, etc. The same was true for the Electrical Engineering undergraduate program on campus: there was only one female professor. Thus, there seemed to be a lack of representativeness when it comes to women working in these so-called technical areas. In this sense, the teacher-researcher could observe the need to address several topics-including gender stereotypes and sexism-in the educational context.

In regards to the focus on media texts in the task-cycle and, more specifically, the real-world linguistic outcome of producing an infographic, the needs analysis revealed the prevalence of the use of this media in students' daily lives. In this sense, the main objective was for students to develop a critical stance towards not only understanding but also producing media messages, thus questioning and challenging stereotypical notions of gender while presenting and comparing statistics and data.

As aforementioned, the needs analysis period was an important phase for the development of both critical task-cycles in order to attempt to design and implement tasks that were appropriate for the students' contexts and realities. This means that by getting to know the context it was possible to design tasks that would take into consideration students' critical communicative needs. Thus, the target language necessary to accomplish the tasks was also derived from the process of identifying their needs (in Study 1 students had to use the simple past to tell stories, while in Study 2 they had to use the comparative while describing statistics and data). In this sense, in both studies the main theoretical underpinnings of task-based approach and critical language pedagogy, along with the results of the needs-analysis phase, served as the basis for the development of the critical task-cycles. However, it must be highlighted that the critical needs analysis is not only a phase that takes place prior to task implementation-it should be an ongoing process that helps us understand and develop strategies that may facilitate critical language development. In both studies, teacher-researchers received ongoing feedback from students-through questionnaires, interviews, and task completion-that helped them in the process of continuously reflecting upon their decisions. Thus, adjustments to the tasks were made in their implementation (for more on the role of the teacher in the implementation of critical tasks, see Silva [48]).

Results from both studies also point out significant reactions from the students towards the decisions made during task-cycle design and implementation. In study 1 [41], learners were asked in post-task interviews whether they perceived any changes in themselves before, during, and after the critical cycle of tasks was implemented. The great majority of students reported they believed they had changed and, in addition to relating their changes to specific linguistic aspects (such as the use of the simple past) or more general language improvements, three different kinds of explanations were brought by them to reason the transformations they believed to have engaged in: they reported (a) being more aware of 
the theme (gender representation); (b) feeling more confident; (c) changing their actions due to the classes.

For Carlos and Batman, the changes happened since they felt more aware of gender representation issues after working in the cycle of tasks. Carlos said "I changed, like, I realize now that it is unfair to the girls". Similarly, Batman pointed out that what changed in him was the fact that, after the cycle of tasks, he learned how to treat girls better. When asked if there were any behavioral changes he could give as an example, his response was: "Hum, to stop calling them names, stuff like that". In Flash's case, the task cycle seemed to have had an impact on her confidence. When asked what changed about her after the classes, Flash said "it feels good to be able to choose my stuff without having to think that I do so because I am a girl". Finally, Isis and Tinho discussed how the classes seemed to have had an impact on their actions. They all reported they learned to avoid reinforcing stereotypes and stop bullying classmates for who they are. Tinho talked to a friend so then he would not pick on his classmates. Isis said that after the classes, she realized she should not bully her peers and, instead, she should respect them.

Considering the learners' voices brought in study 1 , therefore, it is possible to conclude that the theme chosen for the critical cycle of tasks during needs analysis offered learners an opportunity to reflect on gender representation in different ways, which seemed to have impacted their identities, awareness, and even action towards transformation, all of which seem to point towards critical consciousness development. These findings seem, therefore, to reinforce the relevance of critical needs analysis both before and during task implementation.

Likewise, in study 2 , the process of needs analysis seemed to impact learners. However, differently from study 1 , resistance to the theme was observed among some learners which had crucial repercussions on the teacher-researcher as well. In this sense, the ongoing process of needs analysis made the teacher reflect on such resistance and devise appropriate strategies to cope with it. In some of the students' perceptions in the first classes of task implementation, some learners did not regard the critical content of the class (or even the promotion of critical dialogue) as productive. While this could be understood as aligned with their experiences with more traditional or transmission-based types of teaching, what is interesting to observe is that such resistance seemed to have changed throughout the critical task-cycle implementation itself. Thus, it was necessary for the teacher to devise strategies in order to work with students' resistance. This was done by adapting the ways in which the tasks were conceived or implemented in order to better account for the needs that emerged during the implementation process.

In this sense, one significant finding is related to the importance of first understanding students' views in order to engage them in a process of critical language development. In other words, critical issues should not be simply "presented" to them-when the teacher said students" views were "wrong" or when he confronted their opinions saying they contained "prejudice", students resisted and were not open for engaging in a process of critical discussion (for more on this, see the next section). Thus, it is important to allow students to engage in the development of critical consciousness. In this sense, the students reported that the use of statistics or data (such as in the case of the infographic task in Study 2, in which they got to know a study on the influence of the media on teenage girls self-images in the US) was important in order to give grounds for them to build their arguments regarding the influence of the media on/and gender inequality.

Considering the findings previously discussed from both studies, it can be concluded that the ongoing process of critically analyzing students' needs was crucial for understanding the specificities of the context of investigation. The critical needs analysis led to significant decisions made by the teachers, such as focusing on a specific topic that seemed to be relevant for learners' reality or deciding on how to promote critical dialogue in the classroom (see next section). In this sense, it is our belief that a critical needs analysis is a first step towards critical language teaching and it is also a vital aspect in contexts 
such as public schools since it may allow for consciousness raising and transformation to take place.

\subsection{The Use of Critical Dialogue for Fostering Knowledge Co-Construction}

As posed by Lankshear and McLaren [49], "one becomes a critical thinker in the act of practicing critical thought" (p. 42). Engaging in critical dialogue in the additional language classroom, therefore, may be seen as an opportunity for developing students critical consciousness towards their own identity and others', and hopefully towards social change. Several instances of critical dialogue could be observed in both studies. Here, we describe some of these occurrences of classroom interactions to illustrate this matter.

In study 1 [41], for instance, during the completion of Task 1, learners had played a game in which they would unveil stereotypical associations usually made regarding gender. After playing the game, students and the teacher-researcher engaged in a discussion concerning the game results. One situation addressed during discussion was related to gender and soccer. At that time, Carlos commented that although he understood sport abilities are not determined by gender, he knew for a fact that boys know more about soccer than girls. The teacher-researcher used Carlos' comment as an opportunity for promoting critical dialogue and asked the whole class if they could tell why boys usually seemed to know more about soccer than girls. As a response, most girls complained that adults in their lives usually do not talk about soccer with them, only with boys.

Pavlenko [50] explains that, in the classroom, "the multiple forms of engagement should aim at offering a safe place in which students could learn to recognize and acknowledge existing gender discourses and explore alternative discourses, identities, and futures" (p. 63). That seems to be the case in the example herein described, since by having the opportunity to analyze their own reality, students engaged in a critical reflection about different aspects of their culture and about how gender norms are socially constructed and reinforced through stereotypes.

Another moment of the same activity deserves close attention: Thalita's reaction to Carlos' comment. Thalita usually plays soccer with friends and, after Carlos' observation, she seemed to feel bothered by it, responding that she knew as much about soccer as Carlos did. Thalita was usually a very quiet student who seemed to feel really shy to participate. Even so, during this discussion, she voluntarily spoke up, which may show how strongly she felt about Carlos' remark. By raising her voice and questioning Carlos' point of view, Thalita not only empowered herself as a soccer expert, but she also challenged a very common discourse related to women and sports. After she spoke, all the girls clapped and she seemed to be really proud of herself.

Crookes [12] highlights that dialogue in critical classrooms may function as a tool for students to name the world in such a way that others (classmates, teacher, etc.) may review their own perspectives of the posed reality, initiating thus possible changes and transformations. Thalita's commitment to the discussion after Carlos' statement and the impact of her self-assurance in front of the whole class can be seen as an example of students engaging in dialogue towards critical consciousness development. As McLaughlin and DeVoogd [51] explain, problematizing and asking questions on common sense views through critical dialogue in the classroom may give learners a chance to acknowledge and better understand the complexity of a given situation and, therefore, be better equipped to change it.

Another interesting example of critical dialogue can be observed in study 2 [42], this time involving a discussion closely guided by the teacher-researcher. During class 7 , the students worked on Task 5 and analyzed an ad from 1968 that contained the image of a female astronaut and the sentence "Women of the future will make the moon a cleaner place to live". With the teacher's guidance, the students could realize that the ad makes a connection between women and the act of cleaning, a stereotype which is still present in contemporaneity. A few students replied, though, saying that commercials were not the same anymore, since they feature men as well. The teacher tried to question them on 
whether this ad would be published in current Brazil, to which the students replied saying that it would not make sense and it would probably lead to legal problems. Then, the teacher-researcher attempted to value the students' responses by acknowledging that there have been changes in commercials and in the way women and men are represented, but that the association of women with cleaning is still very common: "[So in the ad we have] Women connected to cleaning. We still have this. But there are changes, right, Robson?".

As the class continued, other students shared their views emphasizing that since commercials intend to sell certain products, it is justifiable that they rely on commonsensical discourses or representations. The students' views that commercials have the objective of selling a specific product show an understanding of media messages' intentions. However, they seemed to fail to acknowledge that promoting stereotypical views of men and women is indeed a problem. In this sense, rather than contradicting them, the teacher tried to stimulate reflection: At first, he said that we need to keep in mind media interests (reinforcing what the students had already mentioned), and then he talked about how gender roles are constructed socially and may differ from culture to culture. The teacher explained, then, that since such gender roles are constructed, they are not static and can therefore be changed. Some students argued, then, that men are stronger and this comes from prehistoric times and that there is a "tendency" for roles to be the way they are. Based on that, the teacher said that it is necessary to avoid justifying gender roles on biological terms, since they are actually constructed socially. In this sense, the teacher tried to move deeper in the discussion by wrapping it up, saying that men and women should be able to perform the activities they want to (such as in the area of Mechanics), and that the problem with these commercials is that they reinforce the idea of gender division. As Louro [52] states, the argument that men and women are distinct biologically and that their unequal relations is a result of that is simplistic since it ignores that gender inequality is actually produced based on how such differences are overemphasized, represented, and signified. This means that what is said or thought about men and women is constructed, thus, it varies and is dependent upon each society and historical moment.

The teacher also tried to make the reflection more palpable for the students by referring to their specific context of study. Thus, he asked them how many girls there are in the Mechanics program and emphasized that the reason for that is not biological, but rather social and cultural. This seemed to be effective, since the same student who did not see a problem in the commercial appeared to understand the teacher's argument-he contributed to the discussion by saying that he had seen on the news a tribe whose culture had other roles for men and women. However, later on this student said that he agreed with the idea that there are generalizations and stereotypes, but he still thought that the producers are not "doing anything wrong" since they are trying to reach their objectives, which consists in selling a product to a specific audience/consumer. The student, in this sense, is engaged in a process of critical reflection, but one can observe that his views are still guided by a capitalist understanding of society—or by the myth of free market pointed out by Freire [13]. The teacher then tried to bring the view that it is important to reflect on the influences and the impact that these commercials have on society, since they do not only reflect reality but also construct it. Even though students' thinking still seems to be pervaded by certain myths [13], we see these moments in which the students engaged in the discussion as examples of critical dialogue taking place, as learners expressed their points of view and were open to listen to others. These are, therefore, very important steps towards critical development.

From the instances described above, it can be perceived that critical dialogue seems to be an important aspect of critical language teaching. As explained by Crookes [12], from a Freirean perspective, dialogue is used for naming and transforming the world and that takes place through knowledge co-construction and interaction. The occurrences previously brought illustrate interactions among students and between students and the teacher-researchers that indicate moments of critical reflection motivated by dialogue. Data analysis reinforces, therefore, the crucial role of critical dialogue in language classrooms 
as a way to aid learners in their process of reading the world through the word and empowering them in the direction of self and world transformation. Moreover, the findings here explored also highlight the teacher's pivotal role in promoting opportunities and/or making use of decisive moments in class to initiate/motivate/encourage critical dialogue in order to foster critical consciousness development among learners.

\subsection{The Development of Final Projects to Challenge Common-Sense Discourses}

Christensen [53] talks about the importance of "creating spaces for students to tackle larger social issues that have urgent meaning in their lives" (p. 220). The author claims that, by investigating their own contexts beyond classroom walls and writing about issues that are part of their reality, students have a chance to "identify not only how their lives are affected by society, but also how other people's lives are distorted or maligned by the media and by historical, literary, and linguistic inaccuracy" (p. 222). In a similar direction, McLaughlin and DeVoogd [51] explain that engaging in production activities after reading activities is a way of extending students' critical thinking, giving them an opportunity to challenge commonplace discourse and raise their voice towards social justice. Considering the aforementioned, both studies aimed at promoting a critical reaction from the students part, offering them a chance to systematize their knowledge on gender representation and, by investigating their own context, challenge gender stereotypes through production activities while continuing the process of critical language development.

In study 1 [41], learners were invited to write stories in English about overcoming gender prejudice based on interviews with people from their own school. Once the story was complete, it was posted on a Facebook page created by the students inspired on the website Humans of New York. By engaging in such project, learners in study 1 had the opportunity to go beyond reflection, aiming at the initial transformation of their reality, that is, they could promote alternative gender representations in their own micro context, their school. While exploring their own reality and investigating stories in their own school community, students had the chance to learn about different experiences and express multiple voices, thus challenging stereotypical representations of gender. They were also empowered to celebrate their own identities and embrace their own versions of gender stories. In Giroux's [54] words, "educating for difference, democracy, and ethical responsibility is not about creating passive citizens. It is about providing students with the knowledge, capacities, and opportunities to be noisy, irreverent and vibrant" (p. 374). Moreover, the National Curricular Parameters [1] also emphasize the importance of: developing citizenship and adopting attitudes of solidarity, cooperation and rejection of injustice; adopting a critical stance with the use of dialogue to mediate conflicts; positioning oneself against any form of discrimination based on cultural differences, such as class, beliefs, sex, ethnicity or any other individual or social characteristic; understanding oneself as part of, dependent of, and a transformation agent of society, contributing to the preservation of the environment; questioning reality and proposing solutions for problems through the use of logics, creativity, intuition, and critical analysis; etc. (p. 7-8).

Similarly, in study 2 [42], the students had to produce their own media text. After having learned and reflected on media gender representation and the world of work, as well as reflected on the status of the mechanical technician and the gender roles in their school, they had to gather information regarding women in the area of Mechanics in order to build an infographic about gender and Mechanics. By doing that, they could challenge stereotypical and patriarchal notions of gender in the area of engineering and in the mechanical technician program (since, as we have seen, this was perceived as a critical need of the students enrolled in the Mechanics program).

As Kellner [55] suggests, "developing critical consciousness should empower individuals through enabling them to learn to see through the mystifications of their environment, to see how it is constructed and operates, and to see how they can free themselves from dominating and oppressive aspects and learn to remake society as a mode of self and social activity" (p. 80). The author also points out that looking at advertising from a 
critical perspective allows for the understanding of how such texts shape our realities (p. 66). In this sense, we argue that approaching gender stereotypes in the media (especially when students have the opportunity to create their own media texts) can help in critically understanding gender roles in the spheres of work, school, and even the home.

As Shin and Crookes [56] stress, "through the awareness of the link between their life issues and the macro sociopolitical, cultural context, they learn to make decisions in and outside the classroom and can eventually take actions outside the classrooms" (pp. 114-115). It is our belief that when learners are offered opportunities for change through critical task cycles that result in class projects, possibilities are created for developing critical consciousness towards learners' own identities and and hopefully towards social change.

\section{Final Considerations}

In this article, the discussion we engaged in indicates that conducting research in a language classroom may be an opportunity for exercising learners' agency and teachers' investigatory profile. Hence, additional language classrooms not only can but also must become a site for social transformation through critical pedagogy principles.

In both studies, critical task-cycles were created and used for critical language development and critical consciousness development. Some significant elements were highlighted as important aspects that make the two units into critical task-cycles: (i) a task-based framework; (ii) a clear communicative and critical outcome; (iii) opportunities for critical language development; (iv) opportunities for critical consciousness development by reflecting upon and challenging texts and discourses in society, with a focus on social justice and transformation of local contexts. Moreover, after comparing and analyzing data derived from both studies, three main aspects were perceived as primordial in order to promote critical language development through critical task-cycles: (1) the process of critically analyzing students' contexts and needs in order to develop and implement activities and strategies that would foster critical consciousness development; (2) the promotion of critical dialogue - with the teacher's mediation - to allow students to reflect on a social topic by juxtaposing their views to their peers' and by pondering upon them based on data and solid arguments; and (3) the use of final projects that allow students to not only better understand their reality but also take action aiming at social justice.

Despite the fact that from the perspective of Critical Pedagogy there is no specific recipe for teaching and for designing teaching materials (since the teaching-learning context should guide the process of design and implementation), we agree with Crookes [12] who advocates for the need of developing sample materials and of producing accounts of experiences of critical language teaching. After all, it is important that teachers and educators in general understand how critical language teaching may function in the real classroom. In this sense, the analyzed data points out to some possibilities for language teaching - which would include the necessity of understanding one's teaching contextand the need to have the student at the center of the teaching-learning process-which would entail understanding students' positions in the world and allowing them to engage in the process of critical development in order to promote social change. In this sense, we understand that the teacher has a fundamental role in guiding this process and has to be able to provide students with tools for thinking critically rather than present them with already-made arguments.

This article also reinforces that Critical Language Teaching is possible (and necessary!) in schools and that approaching language teaching from such a critical perspective in the current political scenario is actually an act of resistance. In this sense, we claim that teaching critically, even though it may be "dangerous work" [57] for those who engage in it, is indeed indispensable if we recognize that education itself is political and should therefore aim at promoting social justice.

As Duboc and Ferraz [58] explain, "any educational project aimed at a critical perspective must depart from the pain and complexities, regardless of the lack of prompt responses" (p. 229). Despite the fact that recurrent daunting news seem to suggest that 
researchers and educators are powerless in the sense that several changes are imposed on us without public consultation [vii], we see critical task-cycles as a possibility for the development of counter-hegemonic pedagogical practices. In a context marked by social and political turmoil, we agree with the necessity of "a critical attitude between the gaps (or between the cracks) of the curriculum by deconstructing discursive practices which constantly arise in the classroom, be they in textbooks, curricular guidelines, or the students' and the teacher's perceptions, ideas, and values" [58] (p. 241). It is a challenge that we proudly urge to accept.

Author Contributions: Both authors contributed equally to all steps of this study. All authors have read and agreed to the published version of the manuscript.

Funding: This research received no external funding.

Institutional Review Board Statement: The data from this article derives from studies conducted according to the institutional guidelines for studies involving humans in Brazil. Thus, both original studies were approved by the Ethics Committee at Universidade Federal de Santa Catarina (protocol codes 2.032.334 and 2.229.041). Pseudonyms were used in this article to ensure participants' anonymity.

Informed Consent Statement: Informed consent was obtained from all subjects involved in the study.

Data Availability Statement: Complete sets of the data herein presented can be found in the authors' original studies [41,42].

Conflicts of Interest: The authors declare no conflict of interest.

\section{References}

1. Brasil. Parâmetros Curriculares Nacionais; MEC/SEF: Brasília, Brazil, 1998.

2. Brasil. Parâmetros Curriculares Nacionais: 3 o e 4o Ciclos do Ensino Fundamental: Língua Estrangeira; MEC/SEF: Brasília, Brazil, 1998.

3. Brasil. Orientações Curriculares Para o Ensino Médio: Linguagens, Códigos e Suas Tecnologias; MEC/Secretaria de Educação Básica: Brasília, Brazil, 2006.

4. Brasil. Base Nacional Comum Curricular; MEC/SEF: Brasília, Brazil, 2017.

5. Farias, P.F.; Silva, L. I'm gonna leave you with the backlash blues: Uma análise acerca da concepção do ensino de língua inglesa na base nacional comum curricular sob o viés da pedagogia crítica. Revista e-Curriculum. 2020, 18, 137-157. [CrossRef]

6. Frigotto, G. Escola "Sem" Partido; Laboratório de Politicas Públicas UERJ: Rio de Janeiro, Brazil, 2017.

7. Freire, P. Pedagogia da Esperança; Paz e Terra: Rio de Janeiro, Brazil, 1992.

8. Ellis, R. Position paper: Moving task-based language teaching forward. Lang. Teach. 2017, 50, 507-526. [CrossRef]

9. Ellis, R. Task-Based Language Learning and Teaching; Oxford University Press: Oxford, UK, 2003.

10. Skehan, P. A Framework for the Implementation of Task-Based Instruction. Appl. Linguist. 1996, 17, 38-62. [CrossRef]

11. Skehan, P. Tasks Versus Conditions: Two Perspectives on Task Research and Their Implications for Pedagogy. Annu. Rev. Appl. Linguist. 2016, 36, 34-49. [CrossRef]

12. Crookes, G.V. Critical ELT in Action: Foundations, Promises, Praxis; Routledge: New York, NY, USA, 2013.

13. Freire, P. Pedagogy of the Oppressed; Continuum: New York, NY, USA, 1970.

14. Rajagopalan, K. Por Uma Linguística Crítica. Ling. Let. 2007, 8, 13-20.

15. Knoblauch, C.H.; Brannon, L. Critical Teaching and the Idea of Literacy; Boyton/Cook Publishers: Portsmouth, UK, 1993.

16. Cox, M.I.P.; Assis-Peterson, A.A. Critical pedagogy in ELT: Images of Brazilian teachers of English. TESOL Q. 1999, 33, 433-452. [CrossRef]

17. Brahim, A.C.S.M. Pedagogia crítica, letramento crítico e leitura crítica. Rev. X 2007, 1, 11-31.

18. Siqueira, D.S.P. Inglês como língua internacional: Por uma pedagogia intercultural crítica. In Ensinar e Aprender Linguas na Contemporaneidade: Linhas e Entrelinhas; Silva, K.A.D., Ed.; Pontes: Campinas, Brazil, 2010; pp. 25-52.

19. Siqueira, D.S.P. Como abordar questões ideológicas nas aulas de línguas estrangeiras. In Ensino e Aprendizagem de Língua Inglesa: Conversas Com Especialistas; LIMA, D.C.D., Ed.; Parábola Editorial: São Paulo, Brazil, 2009; pp. 79-92.

20. Moita Lopes, L.P. Por uma Linguística Aplicada Indisciplinar; Parábola: São Paulo, Brazil, 2006.

21. Moita Lopes, L.P. Linguística Aplicada como lugar de construir verdades contingentes: Sexualidades, ética e política. Gragoatá 2009, 27, 33-50. [CrossRef]

22. Moita Lopes, L.P. Os Novos Letramentos Digitais Como Lugares De Construção De Ativismo Político Sobre Sexualidade e Gênero. Trab. Linguística Apl. 2010, 49, 393-417. [CrossRef]

23. Pessoa, R.R. A critical approach to the teaching of English: Pedagogical and identity engagement. Rev. Bras. Linguistica Apl. 2014, 14, 353-372. [CrossRef] 
24. Pessoa, R.R.; Urzêda-Freitas, M.T. Língua como espaço de poder: Uma pesquisa de sala de aula na perspectiva crítica. Rev. Bras. Linguística Apl. 2016, 16, 133-156. [CrossRef]

25. Silva, L.; Farias, P.F.; D’Ely, R. Doing Critical English Language Teaching: Designing critical tasks to promote critical media literacy. A Cor das Let. 2018, 18, 99-121. [CrossRef]

26. Pessoa, R.R.; Andrade, M.E.S.F.; Ferreira, E.P. A Critical Teacher Education Experience in the State of Goiás, Brazil. Rev. Bras. Linguística Apl. 2018, 18, 339-366. [CrossRef]

27. Ferreira, A.D.J. Educação Linguística Crítica e Identidades Sociais de Raça. In Perspectivas Crítica de Educação Linguística no Brasil: Trajetórias e Práticas de Professoras(es) Universitárias (os) de Inglês; Pessoa, R.R., Silvestre, V.P.V., Monte Mór, W., Eds.; Pá de Palavra: São Paulo, Brazil, 2018; pp. 41-48.

28. Souza, L.M.T.M.; Monte Mór, W. Afterword Still Critique? Rev. Bras. Linguística Apl. 2018, 18, 445-450. [CrossRef]

29. Siqueira, D.S.P. English as a lingua franca: For a critical intercultural pedagogy. Intercult. Commun. New Perspect. ELF 2016, 1, 189-209.

30. Long, M.H. Second Language Acquisition and Task-Based Language Teaching; Wiley-Blackwell: Oxford, UK, 2015.

31. D'Ely, R. A Focus on Learners' Metacognitive Processes: The Impact of Strategic Planning, Repetition, Strategic Planning Plus Repetition and Strategic Planning for Repetition on L2 Oral Performance. Ph.D. Dissertation, Universidade Federal de Santa Catarina, Florianópolis, Brazil, 2006.

32. D'Ely, R. The impact of familiarity with strategic planning and teacher-led planning on learners' L2 oral performance of focused and unfocused tasks. In Contextualized Practices in EFL Teaching and Assessment; Tumolo, C.H.S., Figueiredo, D.C., Moritz, M.E.W., D’Ely, R., Eds.; UFSC: Florianópolis, Brazil, 2011; pp. 1-27.

33. Specht, A.L. Is Strategic Planning Enough? Investigating the Impact of Two Types of Strategy Instruction on Students' Oral Planned Performance. Ph.D. Dissertation, Universidade Federal de Santa Catarina, Florianópolis, Brazil, 2017.

34. Specht, A.L. The Impact of Strategic Planning Instruction on Learners? Accurate Oral Performance of English as an L2. Master Thesis, Universidade Federal de Santa Catarina, Florianópolis, Brazil, 2014.

35. Pereira, G.D. The Development and Implementation of Tasks to Elderly Learners of English as a Foreign Language: Taking a Bigger Picture into Consideration. Master's Thesis, Universidade Federal de Santa Catarina, Florianópolis, Brazil, 2015.

36. Afonso, J.C. What Role do Tasks Play in an EFL Environment? Unfolding 9th Grade Learners' Perceptions on the Implementation of a Cycle of Tasks on the First Chapter of 'Harry Potter and the Sorcerer's Stone'. Master's Thesis, Universidade Federal de Santa Catarina, Florianópolis, Brazil, 2016.

37. Zaccaron, R. The More the Merrier? The Impact of Individual and Collaborative Strategic Planning on Performance of an Oral Task by Young Learners of English as an L2 in Brazil. Master's Thesis, Universidade Federal de Santa Catarina, Florianópolis, Brazil, 2018.

38. Trevisol, J.R. Investigating L2 Learners Production and Perception of a Cycle of Tasks with Digital Storytelling: An Exploratory Study in Technology-Mediated TBLT. Ph.D. Dissertation, Universidade Federal de Santa Catarina, Florianópolis, Brazil, 2019.

39. Marcelino, A.F.B. TBLT and Portuguese as a Host Language: Analyzing Learners' Oral Performance in Terms of Outcome Achievement and Investigating the Task Implementation Process through the Learners' and the Teacher's Perspectives. Master's Thesis, Universidade Federal de Santa Catarina, Florianópolis, Brazil, 2020.

40. Farias, P.; D’Ely, R. Task Design and Implementation for Beginning-Level Elementary School Learners in South-Brazil: Challenges and Possibilities. In Using Tasks in Second Language Teaching; Lambert, C., Oliver, R., Eds.; Multilingual Matters: Bristol, UK, 2020; pp. 178-193.

41. Farias, P.F. Critical EFL and Critical Literacy: The Impacts of Designing and Implementing a Cycle of Tasks In a Public School Setting for Critical Language and Critical Literacy Development. Ph.D. Dissertation, Universidade Federal de Santa Catarina, Florianópolis, Brazil, 2018.

42. Silva, L. Teaching English for Critical Language Development: Investigating the Implementation of Critical Cycle of Tasks in the Context of Basic and Technological Education. Ph.D. Dissertation, Universidade Federal de Santa Catarina, Florianópolis, Brazil, 2018.

43. Ellis, R.; Shaofeng, L.; Yan, Z. The effects of pre-task explicit instruction on the performance of a focused task. System 2019, 80, 38-47. [CrossRef]

44. DeKeyser, R. Beyond focus on form: Cognitive Perspectives on learning and practicing second language grammar. In Focus on Form in Classroom Second Language Acquisition; Doughty, C., Williams, J., Eds.; Cambridge University Press: Cambridge, UK, 1998; pp. $42-63$.

45. Crookes, G.V.; Ziegler, N. Critical Language Pedagogy and Task-Based Language Teaching: Reciprocal relationship, mutual benefit. Educ. Sci. 2021. under review.

46. Schmidt, R. The role of consciousness in second language learning. Appl. Linguist. 1990, 11, 129-158. [CrossRef]

47. Benesch, S. Needs Analysis and Curriculum Development in EAP: An Example of a Critical Approach. TESOL Q. 1996, 30, 723-738. [CrossRef]

48. Silva, L. Critical tasks in action: The role of the teacher in the implementation of tasks designed from a critical perspective. Ilha do Desterro A J. Engl. Lang. Lit. Engl. Cult. Stud. 2020, 73, 109-128. [CrossRef]

49. Lankshear, C.; McLaren, P.L. Critical Literacy: Politics, Praxis and the Postmodern; State University of New York Press: Albany, NY, USA, 1993. 
50. Pavlenko, A. Gender and sexuality in foreign and second language education: Critical and feminist approaches. In Critical Pedagogies and Language Learning; Norton, B., Toohey, K., Eds.; Cambridge University Press: Cambridge, UK, 2004.

51. McLaughlin, M.; DeVoogd, G. Critical Literacy: Enhancing Students' Comprehension of Text; Scholastic: New York, NY, USA, 2004.

52. Louro, G.L. Gênero, Sexualidade e Educação: Uma Perspectiva Pós-Estruturalista, 16th ed.; Vozes: Petrópolis, Brazil, 2017.

53. Christensen, L.M. Critical Literacy: Teaching Reading, Writing, and Outrage. In Making Justice Our Project: Teachers Working toward Critical Whole Language Practice; Edelsky, C., Ed.; National Council of Teachers of English: Urbana, IL, USA, 1999.

54. Giroux, H. Literacy and the politics of difference. In Critical Literacy: Politics, Praxis and the Postmodern; Lankshear, C., McLaren, P.L., Eds.; State University of New York Press: Albany, NY, USA, 1993.

55. Kellner, D. Reading images critically: Toward a Postmodern Pedagogy. In Postmodernism, Feminism, and Cultural Politics; Giroux, H.A., Ed.; SUNY: New York, NY, USA, 1991; pp. 60-82.

56. Shin, H.; Crookes, G. Exploring the possibilities for EFL critical pedagogy in Korea-A two-part case study. Crit. Inq. Lang. Stud. Int. J. 2005, 2, 113-138. [CrossRef]

57. Pennycook, A. Critical Applied Linguistics: A Critical Introduction; Taylor \& Francis: Mahwah, NJ, USA, 2009.

58. Duboc, A.P.M.; Ferraz, D.D.M. Reading ourselves: Placing critical literacies in contemporary language education. Rev. Bras. Linguística Apl. 2018, 18, 227-254. [CrossRef] 